\author{
Justyna Bazylińska-Nagler \\ ORCID: 0000-0002-0190-7566 \\ Uniwersytet Wrocławski \\ justyna.bazylinska-nagler@uwr.edu.pl
}

\title{
The right to a clean environment: A warrant of sustainable development?
}

Date of submission: 1 July 2018; date of acceptance: 5 September 2018

JEL Classification: K32, K33, K38, K42

Keywords: sustainable development, right to clean environment, third-generation human rights, Aarhus Convention

\begin{abstract}
The right to a clean environment: A warrant of sustainable development?

Is sustainable development a policy goal or a legal rule? This paper deals with sustainable development as a legal term, and with the right to a clean environment as a human right. Through analyses of international courts case law it tries to prove that effective execution of the substantive right to a clean environment could improve the application of the sustainable development principle. Following the theory which states that the more legal instruments protecting the environment we apply, the more sustainable development is, this paper surveys the legal instruments of sustainable development that can be used as part of the environmental pillar of development. The paper focuses on judicial protection instruments, considering both private and public interest litigation. The conclusion is that legal instruments for the application of sustainable development are inefficient or inadequate. The environment, often referred to as a "common concern" or as "common heritage" of mankind, has no standing before the courts.
\end{abstract}

\section{Introduction}

The concept of sustainable development was originally created to mark the boundaries of economic development. It is an idea which brings together many different policy areas. Some of them are treaty-based policy-guiding principles (EU Sustainable Development Strategy 2006, pp. 1-6). Crucial for giving meaning to the concept of sustainable development are above all: the policy integration 
principle (Article 3(3) Treaty on European Union [TEU]; Article 11 Treaty on the Functioning of the European Union [TFEU]), the "polluter pays" principle and the precautionary principle (Article 191(2) TFEU). Sustainable development is meant to play a central role in the rules and policies of the EU. Moreover, systemic interpretation of the Treaties (TEU, TFEU) leads to the conclusion that sustainable development is a principle of EU substantive law (Geiger, Khan, and Kotzur 2015). EU policy documents - unlike EU law — do offer some guidance on the meaning of sustainable development, usually by referring to the pioneering definition introduced by the UN Bruntland Commission in 1987: "Sustainable development is development that meets the needs of the present without compromising the ability of future generations to meet their own needs" (Bruntland 1987, chapter 2, para. 1). In theory, sustainable development is founded on three pillars: economy, environment and society.

The purpose of this research is to investigate the so-called environmental pillar. The question is: How to execute, from a legal point of view, this environmental pillar of sustainable development? Could the individual right to a clean environment be of any assistance? The main hypothesis of this work is that the effective execution of the right to a clean environment would strenghten the environmental pillar of sustainable development. Therefore, the subjects of this paper are: sustainable development as a legal term, the right to a clean environment as a human right, and finally, the execution of the substantive right to a clean environment as a component of sustainable development.

\section{Theoretical framework of the research: Literature review}

The subject of the legal status of sustainable development as either policy goal, legal principle or legal rule has been addressed by researchers such as Jerzy Jendrośka (2013), Ludwig Krämer (2016), Luis Avilés (2012), Sander van Hees (2014). However, they present differentiated opinions that deserve an extended commentary in this work.

The vexing problem of procedural guarantees of the right to environment, understood as an individual right or general - third-generation - human right, has been discussed by a significant number of authors. The majority has focused on private enforcement of the right to environment as one of human rights (Bándi 2014; Boyle 2015; Cenevska 2016; Mancewicz 2007). There is an almost complete agreement among scholars that the right to a clean environment should belong to the category of human rights, however, for the moment it is very difficult to execute this right. Additionally, it is worth mentioning that the United Nations have repeatedly attempted to institutionalize, at the global level, the obvious connections between the human rights protection system and environmental 
protection. The Ksentini report (Human rights and the environment: Final report, E/CN.4/Sub.2/1994/9), prepared for the United Nations Commission on Human Rights in 1994, is a good example. Finally, in March 2012 the UN Human Rights Council decided to establish an Independent Expert on Human Rights and the Environment (United Nations A/HRC/19/L.8/Rev.1).

Certainly not popular, however, also discussed by some authors, is the concept of public interest litigation concerning environmental matters before human rights courts (Schall 2008) or before the Court of Justice of the European Union (CJEU) (Garçon 2015; Krawczyk 2012; Krämer 2015, 2016; Müller 2011; Poncelet 2012). Most of them came to the conclusion that there is a legislative gap concerning the enforcement of environmental law in public interest, both at EU level and in domestic systems (Poncelet 2012, p. 308; Schall 2008, pp. 443, 452).

At the same time, there are relatively few literature studies dealing with procedural guarantees of sustainable development. For example, enforcing sustainable development through the courts was discussed by Sander R.W. van Hees (2014) and Alan Boyle $(2008,2015)$, who noticed that the role of the courts in this context could be dualistic. First of all, they could be guardians of the procedural contours of sustainable development. From this perspective, the courts can review the way decisions about development are made through evironmental impact assessment, public participation, inter-state consultation. However, they do not review the sustainability of the development on its merits. Secondly, the courts could review the sustainability of economic development by referring to its long-term detrimental effect on human rights, in particular the right to life, private life and property, including economic, social and cultural rights. For the moment, no international court has endorsed this approach, but it has been adopted by the International Law Association Committee on Sustainable Development (2006, pp. 495-499; Boyle 2008).

This work is following Boyle's concept (2008), making an attempt to determine the legal meaning of "sustainable development" and above all trying to verify whether there is any "justiciable right to sustainable development".

\section{Research approach}

This paper considers two fundamental questions: (1) how to enforce sustainable development, in particular its environmental pillar, as a legal rule; and (2) whether enforcement of the right to a clean environment contributes to the application of the sustainable development rule.

The research method is based on legal dogmatic analysis of the relevant provisions of international treaties and official documents, enriched with international courts decisions. These analyses will illustrate to what extent the courts have used sustainable development as a principle or a concept when adjudicating cases. That 
should be helpful in determining the legal status of sustainable development, and finally, defining the relationship between environment, development and human rights in international law.

\section{Research results}

\subsection{Legal definition of sustainable development}

In public international law, in particular in the 1992 Rio Declaration on Environment and Development (invoked by international courts in several cases), there is no explicit proclamation of a "right to sustainable development", nor is there a right to its mirror image - a "clean environment" (Kenig-Witkowska 2017, p. 64; Cordonier, Segger, Khalfan 2011).

Unquestionably, the procedural contours of sustainable development have been defined by international courts. For example, in a case concerning a dispute between Slovakia and Hungary on Gabcikovo-Nagymaros Dam, the International Court of Justice referred for the first time to "this need to reconcile economic development with protection of the environment [that] is aptly expressed in the concept of sustainable development" (ICJ Reports 1997, p. 7, para. 140). In that decision, the ICJ required the parties for the first time, in the interests of sustainable development to reconsider the environmental consequences and to carry out monitoring measures in line with standards set by international law. Thus, it can be easily claimed that the court applied sustainable development as a legal rule to control an international agreement. In this sense, in public international law we can talk about a "right to sustainable development". John Gillroy and Luis Avilés reasonably noted that sustainable development is recognized as a general principle of international law, however, to resolve a legal dispute a legal principle must be recognized and be capable of generating rules (Avilés 2012, p. 30).

European Union law does not give specific, enforcable definitions either. Article 3(3) TEU determines the general environmental objectives of the European Union: "The Union shall work for the sustainable development of Europe, based on [...] a high level of protection and improvement of the quality of the environment". These general goals are complemented by the specific objectives set in Article 191 TFEU. In this way, the concept of sustainable development was introduced to EU Treaty law without being defined. For over 30 years, commentators have been discussing the "vagueness" of sustainable development. There is no coherent conclusion following these discussions. Ludwig Krämer interprets the different provisions on sustainable development in the Treaty and their practical application as giving more of a guideline to policy action than any meaningful legal concept (Krämer 2016, p. 12). Some of the authors agree that sustainable development remains a collection of competing subprinciples and 
through them it becomes partially enforcable (Avilés 2012, p. 30; Jendrośka 2013, pp. 1046-1047). The policy integration principle is recognized by numerous international and EU legal sources (Article 11 TFEU) as a key element of sustainable development. At the same time, these sources reveal that policy integration is not the goal of sustainable development but merely a tool to achieve sustainable development (van Hees 2014, p. 63).

Of all the principles addressed in the CJEU case law, the principle of assuring a high level of environmental protection is the most integral to the implementation of sustainable development in the EU law (C-302/86, Danish Bottles, para. 8-11). The binding character and legal meaning of this so-called subprinciple of a "high level of environmental protection" remains ambiguous, especially if it concerns its enforcement before courts (Macrory 2006, pp. 20-21). Some authors explicitly claim that these treaty provisions are not justiciable (Jans, Vedder 2012, p. 42). However, decisions of the CJEU concerning the conformity of certain secondary law acts with the principle of a high level of environmental protection confirm that this obligation remains under judicial control (C-284/95, Safety Hi-Tech Srl v. S.\&T. Srl, para. 49-55; T-229/04, Kingdom of Sweden v. Commission of the European Communities, para 262-263: "both branches of the set of pleas in law alleging infringement of Article 5 of Directive 91/414, breach of the principle of integration, breach of the precautionary principle and breach of the principle that a high level of protection should be ensured must be substantially accepted [...] the contested directive must be annulled"; C-14/06 and C-295/06 European Parliament and Kingdom of Denmark v. Commission of the European Communities, para. 74, 75). This view is also shared by Jerzy Jendrośka (2013, pp. 1034-1035).

\subsection{Legal instruments of the environmental pillar of sustainable development}

Without doubt, legal protection of the environment in Europe enhances sustainable development. In theory, the more legal instruments protecting the environment we apply, the more sustainable development is. At this point the crucial problem appears: how to make politicians, governmental institutions, business, NGOs and citizens not only politically but also legally (!) accountable for failing to comply with the objectives of sustainable development? First of all, sustainable development requires policy-makers to apply a balanced decision-making process that should be based on the so-called sustainability impact assessment (Krämer 2016; van Hees 2014, pp. 72-75). Secondly, a whole variety of judicial protection instruments should be used. The goal would be to employ both private interest and public interest litigation to defend the right to a clean environment, defined not only as belonging to a general, abstract category of third-generation human rights, but also as a private, subjective, justiciable right of an individual. 
An important characteristic of environmental law is that private interests that could drive its enforcement frequently do not exist. The evironment is often referred to as a "common concern" or even as "common heritage" of mankind (Schall 2008, p. 420). Public interest litigation helps to exercise control over the public authorities, and also the judicial review of any official action strengthens the rule of law. This is particularly true in the environmental law sector where a lack of interest in enforcement is often a problem. Therefore, it is crucial to note the important role of non-governmental organizations (NGOs) in representing public interest. The value of NGOs in the protection of human rights and the environment is widely recognized. However, the admissibility of public interest litigation is also a complex matter of procedural rights (Garçon 2015).

The European Convention on Human Rights does not include a right specifically dedicated to the protection of the environment, neither does it address environmental issues more generally. However, there are numerous cases before the European Court of Human Rights (ECHR), which have indirectly had consequences for environmental protection (Guerra v. Italy 1998; LCB v. UK 1998; López Ostra v. Spain 1995; Powell and Rayner v. the United Kingdom 1990). The human right that is most frequently employed in the fight against environmental degradation affecting individuals is the right to respect for private and family life and for the home as guaranteed in Article 8. It currently protects the whole personal sphere and thus constitutes an extensive right to tackle environmentally relevant decisions near the home.

The European Court of Human Rights consistently does not offer protection from general deterioration of the environment. In the Kyrtatos case the Court confirmed that: "neither Article 8 nor any of the other articles of the Convention are specifically designed to provide general protection of the environment as such" (Kyrtatos v. Greece 2003, para. 52). For that task, the ECHR considered other international instruments and domestic legislation to be more pertinent for dealing with that particular aspect. The ECHR approach in this respect is very narrow, as individuals may have a legitimate interest in certain types of environmental resource if that environmental resource has an objective use value (such as a forest) and a direct impact on the individual. In the Jensen and Rasmussen case, the Court pointed out: "the applicant cannot complain as a representative for people in general, because the Convention does not permit such an actio popularis. The Court is only required to examine the applicant's complaints that he himself was the victim of violation" (Jensen and Rasmussen v. Denmark 2003, p. 15).

However strict the ECHR is in considering the initiation of the proceedings in the public interest, it still refers to environmental instruments stipulating the involvement of the public in environmentally relevant matters. It is especially valuable that in the Taskin and Others case the Court invoked the Aarhus Convention as a suitable instrument for: "Extending conditions for access to the courts in connection with environmental legislation and access to information [...] De- 
veloping public access to information held by the public authorities, in particular by providing for transparent and accessible dissemination of basic information. Promoting public participation in decision-making concerning issues with an environmental impact" (Taskin and Others v. Turkey 2006, para. 99).

In EU law there is no explicit, individual right to a clean environment either. However, in 2005 the European Community became a party to the Convention on Access to Information, Public Participation in Decision-making and Access to Justice in Environmental Matters (known as the Aarhus Convention) by a Council decision, therefore the Convention is binding for EU institutions and for $\mathrm{EU}$ member states. It is worth mentioning that the Aarhus Convention was adopted on 25 June 1998 by the United Nations Economic Commission for Europe in application of Principle 10 of the Rio Declaration and Principle 1 of the Stockholm Declaration. It is considered to be one of the greatest achievements of public international law because it serves as a global framework to strengthen citizens' environmental rights. "This new kind of environmental agreement linking human rights with environmental rights, acknowledges our obligation to future generations and establishes that only the involvement of all stakeholders leads to the sustainable development accomplishement" (UN Economic Commission for Europe 2014). Article 1 clearly states that the Aarhus Convention is about basic human rights, that is the rights of every person: "In order to contribute to the protection of the right of every person of present and future generations to live in an environment adequate to his or her health and well-being, each Party shall guarantee the rights of access to information, public participation in decision-making, and access to justice in environmental matters in accordance with the provisions of this Convention" (UN Economic Commission for Europe 2014, p. 43). It is one of the most explicit provisions of a fundamental right to a healthy environment in public international law. The Convention founds three procedural rights that are often referred to as the three pillars of the Aarhus Convention. First, the right of access to environmental information, that should raise public awareness of environmental concerns and improve transparency of the national administrations and EU institutions (Articles 4-5). Second, the Convention aims at a greater public involvement in the decision-making process, so as to strengthen public support for decisions affecting the environment (Articles 6-8). Finally, the international agreement is intended to entitle individuals as well as NGOs to challenge decisions through effective judicial mechanisms (Article 9). There is a common consent among scholars that giving wide access to justice to the "public concerned" (Article 9(2)) is a general objective of the Aarhus Convention, however, the way this provision has been implemented at EU and national levels remains very controversial (Garçon 2015; Krawczyk 2012; Müller 2011; Poncelet 2012).

Theoretically, both private interest and public interest litigation (for NGOs) protecting the environment should be available under the Aarhus Convention, but in practical terms the Parties (the states) of the Convention are free in the methods 
and the degree to which they want to guarantee access to justice in environmental matters. Article 9(2) gives considerable discretion to the Parties as to which members of the public concerned must have standing. It offers two alternative models of implementation: either the Parties request that the members of the public concerned have a sufficient interest or, alternatively, that they maintain impairment of a right (Müller 2011, p. 508). By fulfilling these conditions we can expect that private interest litigation is to some extent guaranteed. The problem becomes unsolvable when NGOs wish to bring a case to challenge a decision where a request for access to environmental information was ignored, delayed or denied or to challenge the substantive and procedural legality of a decision, act or omission subject to the provisions of Article 6 concerning public participation in decision-making. In these cases NGOs usually can not claim sufficient interests (private) or that their rights (also private) have been violated for this simple reason that they are organizations not individuals.

In the Lesoochranárske zoskupenie case, the CJEU missed the opportunity to reach a decision on Article 9(3) of the Aarhus Convention according to which the Member States have to provide access to justice when members of the public wish to challenge decisions of the state authorities that contravene provisions of national environmental law (Lesoochranárske zoskupenie VLK v. Ministerstvo životného prostredia Slovenskej republiky 2011). In this case, the Slovak NGO challenged the legality of decisions taken by the Slovak Ministry of the Environment to grant derogations to hunters from the system of protection of the brown bear. The CJEU held that the provision was not sufficiently precise and unconditional to be self-executing (!), given that it leaves it for the national law to set certain criteria to be met by the applicant, in this case NGO (Lesoochranárske zoskupenie VLK v. Ministerstvo životného prostredia Slovenskej republiky 2011, para. 44-45). Therefore, the Court held that it is for the national court to interpret its national law in a way which to the fullest extent possible respects the objectives of Article 9(3) of the Aarhus Convention.

\section{Conclusions}

The legal principle of sustainable development occupies a privileged position in the European legal order. Composed of sub-principles enforcable before courts, such as the high level of environmental protection, it becomes a legally binding standard to control the legality of secondary EU law acts. However, academics reasonably share the view that legal instruments for the application of sustainable development are inefficient or inadequate.

The human rights courts ex definitione protecting private interests for the momement play only a complementary role by taking up the environmental jurisprudence anchored in the linkages between human rights and the environment. 
The European Convention on Human Rights can not easily take a further step in protecting the public interest in environmental protection without the required procedural or substantive treaty changes. It can only strive to include more of the environment in existing human rights. The analysis of the case law of both courts (CJEU and ECHR) shows that individuals have a necessarily limited standing to challenge unsustainable development in abstracto or environmental destruction in general in public interest. To conclude, enforcing sustainable development through the courts needs to be introduced through the coming years with numerous cases. Hopefully, in the future international courts will review the substantive sustainability of economic development by referring to a variety of factors - and the impact on human rights will be one of them.

\section{References}

Avilés L.A. (2012), "Sustainable development and the legal protection of the environment in Europe", Sustainable Development Law \& Policy 12, no. 3, pp. 29-34, 56-57.

Bándi G. (2014), "Right to environment — procedural guarantees", in: Environmental Democracy and Law: Public Participation in Europe, ed. G. Bándi, Groningen-Amsterdam, pp. 79-94.

Boer B. (2015), "Environmental law and human rights in the Asia-Pacific", in: Environmental Law Dimensions of Human Rights, ed. B. Boer, Oxford, pp.135-179.

Boyle A. (2008), "Between process and substance: Sustainable development in the jurisprudence of international courts and tribunals", in: Sustainable Development in International and National Law, eds. H.Ch. Bugge, C. Voigt, Groningen, pp. 203-219.

Boyle A. (2015), "Human rights and the environment: Where next?", in: Environmental Law Dimensions of Human Rights, ed. B. Boer, Oxford, pp. 201-239.

Bruntland G.H. (1987), Our Common Future: World Commission on Environment and Development, Oxford.

Bugge H.Ch., Voigt C., eds. (2008), Sustainable Development in International and National Law, Groningen.

Cenevska I. (2016), "A thundering silence: Environmental rights in the dialogue between the EU Court of Justice and the European Court of Human Rights", Journal of Environmental Law 28, pp. 301-324.

Cordonier Segger M-C., Khalfan A. (2011), Sustainable Development Law: Principles, Practices, and Prospects, Oxford.

FIDE 2012 report, http://www.cedu.direito.uminho.pt/uploads/Relat\%C3\%B3rio\%20FIDE.pdf (accessed: 18.01.2019)

Garçon G. (2015), "Limits of NGO rights to invoke access to justice under the Aarhus Convention", European Journal of Risk Regulation 3, pp. 458-469.

Geiger R., Khan D.-E., Kotzur M., eds. (2015), European Union Treaties: A Commentary. Treaty on European Union. Treaty on the Functioning of the European Union, Munich.

van Hees S.R.W. (2014), "Sustainable development in the EU: Redefining and operationalizing the concept", Utrecht Law Review 10, no. 2, pp. 60-76.

Jans J.H., Vedder H.H.B. (2012), European Environmental Law, Groningen.

Jendrośka J. (2013), “Artykuł 37 Karty praw podstawowych Unii Europejskiej”, in: Karta Praw Podstawowych Unii Europejskiej. Komentarz, eds. A. Wróbel, A. Błachnio-Parzych, Warszawa, pp. 1020-1070. 
Kenig-Witkowska M. (2017), "The concept of sustainable development in the European Union policy and law", Journal of Comparative Urban Law and Policy 1, no. 1, pp. 64-80.

Krawczyk D. (2012), "Case note: The Slovak Brown Bear case. The ECJ hunts for jurisdiction and environmental plaintiffs gain the trophy". Environmental Law Review 14, pp. 53-67.

Krämer L. (2015), "The EU courts and access to environmental justice", in: Environmental Law Dimensions of Human Rights, ed. B. Boer, Oxford, pp. 107-133.

Krämer L. (2016), EU Environmental Law, London.

Macrory R., ed. (2006), Reflections on 30 years of EU Environmental Law: A High Level of Protection?, Groningen.

Mancewicz A. (2007a), "Ochrona środowiska naturalnego prawem człowieka? Prawo do czystego środowiska w świetle orzecznictwa Europejskiego Trybunału Praw Człowieka. Cz. I", In gremio 9, no. 41, pp. 16-20.

Mancewicz A. (2007b), "Ochrona środowiska naturalnego prawem człowieka? Prawo do czystego środowiska w świetle orzecznictwa Europejskiego Trybunału Praw Człowieka. Cz. II”, In gremio 10 , no. 42 , pp. 7-10.

Müller B. (2011), "Access to the courts of the Member States for NGOs in environmental matters under European Union law: Judgment of the Court of 12 May 2011 - Case C-115/09 Trianel and Judgment of 8 March 2011 - Case C-240/09 Lesoochranarske Zoskupenie", Journal of Environmental Law 23, pp. 505-516.

Pallemaerts M., ed. (2011), The Aarhus Convention at Ten: Interactions and Tensions between Conventional International Law and EU Environmental Law, Groningen.

Pavoni R. (2015), "Environmental jurisprudence of the European and inter-American courts of human rights: Comparative insights", in: Environmental Law Dimensions of Human Rights, ed. B. Boer, Oxford, pp. 69-106.

Poncelet C. (2012), "Access to justice in environmental matters: Does the European Union comply with its obligations?", Journal of Environmental Law 24, pp. 287-309.

Schall C. (2008), "Public interest litigation concerning environmental matters before human rights courts: A promising future concept?", Journal of Environmental Law 20, pp. 417-453.

United Nations Economic Commission for Europe (2014), The Aarhus Convention: An Implementation Guide, Geneva.

\section{Legal sources}

Communication from the Commission to the Council and the European Parliament, 2003 Environmental policy review: Consolidating the environmental pillar of sustainable development, COM 2003/745 final.

Convention on Access to Information, Public Participation in Decision-Making and Access to Justice in Environmental Matters, Aarhus, Denmark [1998], 2161 UNTS 447.

Convention for the Protection of Human Rights and Fundamental Freedoms (European Convention on Human Rights (ECHR), ETS No. 005.

Council of the European Union, Renewed EU sustainable development strategy (annex to Council Note 10917/06), 2006.

Decision 2005/370/EC of 17 February 2005 on the conclusion on behalf of the European Community, of the Convention on Access to Information, Public Participation in Decision-Making and Access to Justice in Environmental Matters [2005] OJ L124/1.

Human rights and the environment: Final report, prepared by F.Z. Ksentini, E/CN.4/Sub.2/1994/9.

International Law Association, Report of the seventy-second conference, 2006.

World Commission on Environment and Development (WCED), Our common future, United Nations General Assembly, Doc. A/42/427, Sect.4. 
Treaty on the Functioning of the European Union [2012] OJ C 326/01.

Treaty on European Union [2012] OJ C 326/13.

\section{Case law}

\section{Court of Justice of the European Union}

C-240/09, Lesoochranárske zoskupenie VLK v. Ministerstvo životného prostredia Slovenskej republiky (Brown Bears I), ECR 2011 [I-01255].

C-243/15, Lesoochranárske zoskupenie VLK v. Obvodný úrad Trenčín (Brown Bears II).

C-302/86, Danish Bottles, ECR 1988 [04607].

C-379/08 \& C-380/08, Rafinerie Mediterranee (ERG), ECR 2010 [I-02007].

C-343/09, Afton Chemical Limited v. Secretary of State for Transport, ECR 2010 [I-07027].

C-284/95, Safety Hi-Tech Srl v. S.\&T. Srl, ECR 1998 [I-4301].

T-229/04, Kingdom of Sweden v. Commission of the European Communities, ECR 2007 [II- 2437].

C-14/06 \& C-295/06, European Parliament and Kingdom of Denmark v. Commission of the European Communities, ECR 2008 [I-1649].

\section{European Court of Human Rights}

Guerra v. Italy, 1998, 26 EHRR 357.

Jensen and Rasmussen v. Denmark, 2003, App. No. 52620/99.

Kyrtatos v. Greece, 2005, 40 EHRR 16.

LCB v. UK, 1998, 27 EHRR 212.

López Ostra v. Spain, 1995, 20 EHRR 277.

Powell and Rayner v. the United Kingdom, 1990, 12 EHRR 355.

Taskin and Others v. Turkey, 2006, 42 EHRR 50.

\section{International Court of Justice}

Gabcikovo-Nagymaros Project (Hungary/Slovakia), Judgement, ICJ Reports 1997, p. 7. 